Physical Disabilities: Education and Related Services, 2015, 34(1), 14-30. doi: 10.14434/pders.v34i1.13918

(C) Division for Physical, Health and Multiple Disabilities

\title{
PDERS
}

ISSN: 2372-451X

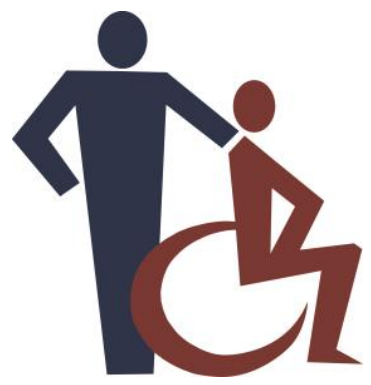

http://scholarworks.iu.edu/journals/index.php/pders/index

Article

\section{SCHOOL PERFORMANCE AND DISEASE INTERFERENCE IN ADOLESCENTS WITH SICKLE CELL DISEASE}

\section{Lori E. Crosby}

Cincinnati Children's Hospital Medical Center \& University of Cincinnati College of Medicine

Naomi E. Joffe

Cincinnati Children's Hospital Medical Center \& University of Cincinnati College of Medicine

\section{Mary Kay Irwin}

Nationwide Children's Hospital

\section{Heather Strong}

Cincinnati Children's Hospital Medical Center \& University of Cincinnati

\section{James Peugh}

Cincinnati Children's Hospital Medical Center \& University of Cincinnati College of Medicine

\section{Lisa Shook}

Cincinnati Children's Hospital Medical Center \& University of Cincinnati College of Medicine

\section{Karen A. Kalinyak}

Cincinnati Children's Hospital Medical Center \& University of Cincinnati College of Medicine

\section{Monica J. Mitchell}

Cincinnati Children's Hospital Medical Center \& University of Cincinnati College of Medicine 


\begin{abstract}
Sickle cell disease (SCD) results in neuropsychological complications that place adolescents at higher risk for limited educational achievement. A first step to developing effective educational interventions is to understand the impact of SCD on school performance. The current study assessed perceptions of school performance, SCD interference and acceptability of educational support strategies in adolescents with SCD. To identify potential risk factors, the relationships between school performance, SCD interference and demographics were also examined. Thirty adolescents aged 12 to 20 years completed demographics and SCD school performance questionnaires. Approximately $37 \%$ of participants reported receiving special education services, but more than $60 \%$ reported that SCD interfered with their school performance. Females reported that SCD impacted their schooling more than males $\left(X^{2}(1, n=30)=5.00, p<.05\right)$. Study findings provide important insights into demographic risk factors and support the need for individualized health and educational plans for adolescents with SCD.
\end{abstract}

Keywords: chronic disease; health disabilities; adolescent health; school performance

\title{
Introduction
}

Sickle cell disease (SCD) is a genetic disorder diagnosed at birth through universal newborn screening. Approximately 1 in 500 African-American children and 1 in 1000 - 1400 HispanicAmerican children are born with SCD each year (Human Genome Management Information System, 2013). SCD is caused by abnormal hemoglobin (i.e., Hemoglobin S), which produces red blood cells that clump together blocking oxygen and blood flow to vital organs and bones. This blockage results in episodic pain and may lead to stroke as well as organ and bone damage. The health complications associated with SCD can leave adolescents more prone to contracting infections (e.g., influenza) as well as more likely to experience complications associated with common infections. In addition, red blood cells containing Hemoglobin $\mathrm{S}$ die faster resulting in hemolytic anemia, nutritional deficits, and delayed puberty (Ashley-Koch, Yang, \& Onley, 2000; Thomas, Singhal, Hemmings-Kelly, \& Serjeant, 2000).

Three decades ago, SCD was thought to be a disease of childhood because many died early in life from SCD-related complications (Telfair, Ehiri, Loosier, \& Baskin, 2004). However, advances in SCD treatment have altered its course such that the majority of children are living into adulthood (Kennedy \& Sawyer, 2008; Quinn, Rogers, McCavit, \& Buchanan, 2010). During adolescence, the risk for medical complications increases due to the cumulative impact of organ and bone damage. As a result, some adolescents will begin to experience chronic pain in their joints or back. Others may require visits to specialists (e.g., pulmonologist) as previously identified medical problems intensify (e.g., asthma-like symptoms worsen without regular treatment). Also, adolescent males may experience some medical complications for the first time (e.g., priapism). 
SCD is expressed differently for each adolescent. SCD pain is unpredictable and can be caused by a number of factors including infection, changes in air temperature, lower oxygen levels, and stress. Some youth have relatively few SCD pain episodes and medical complications, while others require daily medications and/or intensive treatments (e.g., regular blood transfusions) to manage the disease. As a result, adolescents with severe forms of SCD may miss school due to pain episodes that must be managed at home, protracted pain episodes (i.e., crises) that require hospitalization (average 3 to 7 days a year), ongoing treatments such as monthly blood transfusions, and medical appointments to check hemoglobin levels and organ or bone damage (Brown et al., 1993; Gil et al., 2003; King, Tang, Ferguson, \& DeBaun, 2005). One study found that youth with SCD miss 20-30 days per school year (Day \& Chismark, 2006). For adolescents whose treatments result in frequent school absences, academic performance is often compromised (Schwartz, Radcliffe, \& Barakat, 2009; Thies, 1999). Frequent school absences present challenges for school health professionals working with adolescents with SCD (King et al., 2006; Knight-Madden, Lewis, Tyson, Reid, \& Moosang, 2011; Taras \& Potts-Datema, 2005).

Missing school can have significant impact on educational attainment in adolescents with SCD; attainment is measured through grade retention, special education rates, and letter grades (Schatz, 2004). During these absences, students are missing vital academic content. Difficulties associated with missed instruction are further complicated by subject matter that builds on previous knowledge such as mathematics and foreign languages (Thies, 1999). Additionally, adolescents may miss exams and standardized tests (e.g., state equivalency test, Preliminary Scholastic Aptitude Test), that would make them eligible for educational and vocational services, or enrichment opportunities in the future (Schwartz, Radcliffe, \& Barakat, 2006).

In addition to the increased risk for academic problems due to school absences, academic progress is further hindered by the neurocognitive complications that can accompany SCD. Because sickled cells can clump together in the brain, adolescents with SCD are at risk for cerebral vascular infarcts, or strokes, which may result in neurocognitive morbidity (Quinn et al., 2013; Scantlebury et al., 2011). Sometimes adolescents undergo what are referred to as silent strokes, strokes that can only be detected through MRI imaging, not neurologic exam. These silent strokes can result in neurocognitive deficits that may impair reading, language, visual motor processing, memory, attention, and other executive functions (Kral et al., 2003; White \& DeBaun, 1998) which are critical for learning and educational success.

Few studies describe effective educational interventions for this population (see Day \& Chismark, 2006 for a review). Students with SCD who are struggling academically may be eligible to receive educational support services through provisions in the Individuals with Disabilities Education Act (IDEA) of 2004 under the "other health impaired" category (National Dissemination Center for Children with Disabilities, 2012). Yet, Herron Bacak, King and DeBaun (2003) surveyed 39 adolescents with SCD aged 14-19 who had a stroke or three or more hospitalizations in a year and found that only $70 \%$ of those with stroke and $13 \%$ of those with high rates of hospitalizations had an individualized education plan (IEP) or received an evaluation for one. Additionally, all study participants had missed an average of 15 days of school or more (during the previous school year) and $28 \%$ of those with stroke had been retained at least one grade level suggesting that some adolescents with SCD may not be receiving the proper supports and accommodations needed to succeed academically. Ensuring that youth with 
SCD receive appropriate supports and accommodations or an evaluation for special education services is crucial for improving the educational achievement of these students.

King et al. (2006) described a school intervention program for youth with $\operatorname{SCD}(n=23$; mean age $=12$ years) that involved increasing IEP development and educational supports by targeting accommodations such as home tutoring on missed school days. The study team hypothesized that the intervention would lead to an increase in the number of students with SCD who were qualified for special education services, a decrease in grade retention and a decrease in the absenteeism rate two years later. Study results showed that despite intervention, there were not significant decreases in school absenteeism rates or grade retention.

Koontz, Short, Kalinyak and Noll (2004) conducted one of the only randomized trials of a school intervention program for children with SCD. Patients receiving care at a hospital-based pediatric sickle cell clinic in the Midwest, aged 8-12 years $(n=24)$, were randomized to receive routine services $(n=14)$ or school intervention services $(n=10)$. SCD knowledge, satisfaction with the intervention, school absences and self-concept were evaluated. Patients assigned to routine services could request school consultation services from the sickle cell clinic "as needed." Participants in the school intervention group automatically received the following services: (a) an SCD information packet was mailed to the patient's school; (b) hospital educational professionals (staff with a bachelor's degree in education) conducted a peer and/or teacher inservice about SCD (i.e., what it is and common treatments) at the patient's school; and (c) hospital educational professionals consulted with teachers, school nurses, and/or school psychologists to implement individualized educational support services for each patient. Compared to those who received routine services, participants in the school intervention group showed an increase in SCD knowledge and fewer school absences 12 months after the intervention began. The authors hypothesized that parents of children receiving school intervention services felt more confident sending their children to school with minor symptoms resulting in fewer absences. In general, study results supported the need for educational support services to help children with SCD increase their school attendance and opportunities for learning to maximize their ability to reach their full academic potential.

Engelke Guttu, Warren and Swanson (2008) examined a nursing case management intervention for 114 children aged 5 to 19 years who were diagnosed with SCD, asthma, diabetes, severe allergies, or seizures in five school districts. Nursing students developed individualized goals and interventions related to teaching, counseling, working with teachers and families, or making referrals for other services (e.g., reduce SCD pain episodes, improve academic performance, family participates as delineated in the individualized health plan) for children enrolled in the study. They also worked with families to develop an individualized health plan and an emergency plan. At the end of the academic year, study participants showed an improvement in quality of life (as measured by the Pediatric Quality of Life Inventory; Varni, Seid, \& Kurtin, 2001), grades, participation in classroom and extracurricular activities, and disease management (knowledge, skills and confidence to manage a chronic disease).

Although the results of these studies (Engelke Guttu, et al., 2008; Koontz et al., 2011) are promising in decreasing school absences and improving student grades and quality of life, these studies included small samples of adolescents so it is unclear if these interventions would be 
efficacious for the larger population of adolescents with SCD. Furthermore, these studies have yet to be replicated in the literature; this leaves school health professionals with limited guidance about how to develop the most effective interventions for adolescents with SCD. Finally, a recent study of cerebral infarcts in children with SCD (DeBaun et al., 2012) has added to our understanding of the role of neurocognitive deficits in this population. Results suggested that cerebral injury burden has been underestimated in this population and support the need for better understanding the impact of SCD on academic functioning.

An improved understanding of risk factors for school performance in adolescents with SCD and the potential impact of SCD on academic functioning will contribute to the limited literature on school performance in adolescents with SCD and provide targets for interventions that could enhance school health professionals' ability to address educational needs. Understanding how adolescents with SCD perceive different types of educational support strategies will also provide guidance about which strategies are most feasible and acceptable. The current study provides preliminary data on adolescent perceptions of school performance and SCD interference (i.e., how much participants saw SCD as getting in the way of their school performance) and examines the relationship between these variables and demographic factors. Based on a review of the existing literature, it was hypothesized that income and having more than one hospitalization per year (i.e., multiple school absences due to medical complications associated with SCD) would be associated with poorer school performance. A secondary goal of the study was to explore the acceptability of potential educational support strategies and their relationship to demographic variables (e.g., gender, hospitalizations). Study findings provide a more contextual depiction of the school performance of adolescents with SCD and contribute to our understanding of disease interference within the context of pediatric SCD.

\section{Methods}

\section{Participants}

Thirty adolescent patients from a tertiary children's hospital in the Midwest who had been diagnosed with SCD (ages 12-20, $M=16$ years; 50\% female) participated in the study. All participants were enrolled in school at the time of data collection except for two; these participants had been enrolled in school within 12 months of the study. Adolescents were approached about participation during an SCD educational event or camp registration. A total of 47 adolescents attended these events (i.e., were potentially eligible for study participation). Adolescents were eligible to participate if they met the following inclusion criteria: (a) aged 12 to 21 years, (b) receiving care at the children's hospital, (c) diagnosis of SCD, and (d) no significant cognitive limitations per physician report.

Most participants (76.7\%) had the most severe genotype of SCD (HbSS) and reported going to the emergency room for care or being hospitalized in the past year (see Table 1 for full demographic data). With respect to comorbid medical or academic diagnoses, $30.4 \%$ had been diagnosed with asthma $(n=7), 8.7 \%$ had been diagnosed with Attention-Deficit Hyperactivity Disorder $(n=2)$ and $17.4 \%(n=4)$ had been diagnosed with a learning disability. The adolescents in the sample were demographically similar to the 17 adolescents who chose not to participate. 
Table 1

Participant Demographic Data

\begin{tabular}{|c|c|c|}
\hline Variable & $\%(n)$ & $M(\mathrm{SD})$ \\
\hline Mean age & & $16.0(2.3)$ \\
\hline \multicolumn{3}{|l|}{ Gender } \\
\hline Female & $50(15)$ & \\
\hline \multicolumn{3}{|l|}{ Race } \\
\hline African American & $100(30)$ & \\
\hline \multicolumn{3}{|l|}{ SCD genotype } \\
\hline $\mathrm{Hb} \mathrm{SS}$ & $76.7(23)$ & \\
\hline $\mathrm{Hb} \mathrm{SC}$ & $13.4(4)$ & \\
\hline $\mathrm{Hb} \mathrm{SD}$ & $3.3(1)$ & \\
\hline $\mathrm{Hb} \mathrm{S} \beta+$ thalassemia & $3.3(1)$ & \\
\hline $\mathrm{Hb} \mathrm{S} \beta 0$ thalassemia & $3.3(1)$ & \\
\hline \multicolumn{3}{|l|}{$\begin{array}{l}\text { Healthcare utilization within past } 12 \\
\text { months }\end{array}$} \\
\hline Emergency Room & & $1.0(2.6)$ \\
\hline Hospital Admissions & & $1.2(2.0)$ \\
\hline Clinic Visits & & $7.4(6.3)$ \\
\hline \multicolumn{3}{|l|}{ Participating caregiver } \\
\hline Biological parent & $82.7(19)$ & \\
\hline Aunt or uncle & $8.7(2)$ & \\
\hline Step parent & $4.3(1)$ & \\
\hline Other & $4.3(1)$ & \\
\hline \multicolumn{3}{|l|}{ Caregiver education } \\
\hline No high school degree & $21.7(5)$ & \\
\hline High school degree & $21.7(5)$ & \\
\hline Some post-secondary education & $21.7(5)$ & \\
\hline 2-year college degree & $13.1(3)$ & \\
\hline 4-year college degree & $13.1(3)$ & \\
\hline Graduate school degree & $8.7(2)$ & \\
\hline Median family income & $\$ 20,000-\$ 29,999$ & \\
\hline
\end{tabular}

Note. $\mathrm{Hb}=$ hemoglobin.

\section{Procedures}

The study was approved by the Institutional Review Board and designated minimal risk, as no participant identifiers were connected to any of the data collected. After participants and/or their caregivers indicated interest in the study, a member of the research team reviewed the consent form with each participant/caregiver. This review included a discussion of study procedures, potential risks and benefits, and participant rights including the right to receive the same care if they chose not to participate and the right to withdraw from the study at any time. If caregivers and participants aged 18 and over agreed to participate, they were asked to provide written consent. Participants aged 14-17 were asked to also provide written assent (agreement). After 
providing consent, caregivers and participants aged 18 and older completed the demographics form. All participants completed the sickle cell disease school performance questionnaire.

\section{Measures}

Demographics questionnaire. This questionnaire requested participant age, gender, highest grade completed, comorbid medical/academic conditions, parent (primary caregiver) work status, and family household income.

Sickle cell disease school performance questionnaire. This questionnaire consisted of 39 items that were adapted from the Wave 2 Youth Survey of the National Longitudinal Transition Study - 2 (NLTS2) sponsored by the U.S. Department of Education (Wagner, Newman, Cameto, Levine, \& Garza, 2006) by the research team and 15 items about the acceptability of educational strategies that might help adolescents with SCD prepare for post-secondary education, job training, and life skills (e.g., tutoring, assistance with test taking) developed by the research team. The NLTS2 is a 10-year-longitudinal study of educational outcomes for a national sample of students aged 13 to 16 who were in the $7^{\text {th }}$ grade or higher and receiving special education services in 2000. The Wave 2 Youth Survey was completed by 3,360 youth by telephone or mail in 2003 (Newman et al., 2011). The website (http://www.nlts2.org/) and a technical report describe how the survey was developed and report the reliability across respondents (Newman et al., 2011; Wagner, Kutash, Duchnowski, \& Epstein, 2005). Please see Table 2 for an overview of questionnaire domains, the number of items within each domain and sample items for each domain.

\section{Data Analyses}

Descriptive statistics were used to summarize demographic data (e.g., gender, income, number of hospitalizations), school performance, and the acceptability of educational strategies for the overall sample $(n=30)$. Pearson correlations were then calculated to examine the relationship between demographic factors (e.g., gender, parent income, and number of hospitalizations), school performance, and the acceptability of educational strategies. The majority of the results reported include data from all 30 participants; variables with missing data are noted.

\section{Results}

The current study assessed perceptions of school performance, SCD interference and the acceptability of educational support strategies in a sample of adolescents with SCD. To identify potential risk factors, the relationships between school performance, SCD interference and demographics were also examined. Thirty patients with SCD aged 12 to 20 years completed an SCD school performance questionnaire at a camp or educational event. Participants aged 18 and older and caregivers of those under 18 years completed a demographics form. 
Table 2

SCD School Performance Questionnaire Domains and Sample Items

\begin{tabular}{|c|c|c|}
\hline Domain & Number of Items & Sample Item (response options) \\
\hline Grade Retention & 3 & Have you ever repeated a grade (yes, no)? \\
\hline Final Course Grades & 2 & $\begin{array}{l}\text { What was your final grade in math }(\mathrm{A}, \mathrm{B}, \mathrm{C} \text {, } \\
\mathrm{D}, \mathrm{E}, \mathrm{F}) \text { ? }\end{array}$ \\
\hline Special Education Services & 4 & $\begin{array}{l}\text { During the past school year, did you receive } \\
\text { any special education services (yes, no)? }\end{array}$ \\
\hline SCD Interference & 4 & $\begin{array}{l}\text { Do you feel that your sickle cell disease got } \\
\text { in the way of your doing well in school (yes, } \\
\text { no)? }\end{array}$ \\
\hline School Activities & 3 & $\begin{array}{l}\text { During the past school year, did you take } \\
\text { part in any school groups such as sports } \\
\text { teams, clubs, etc. (yes, no)? }\end{array}$ \\
\hline Extracurricular Activities & 3 & $\begin{array}{l}\text { During the past school year, did you take } \\
\text { part in any out of school groups such as } \\
\text { youth groups, sports teams, etc. (yes, no)? }\end{array}$ \\
\hline Employment & 3 & $\begin{array}{l}\text { During the past } 12 \text { months, did you work a } \\
\text { part-time job (yes, no)? }\end{array}$ \\
\hline Academic Skills & 8 & $\begin{array}{l}\text { Please rate how good you are at the } \\
\text { following skills (very good, pretty good, ok, } \\
\text { not very good): } \\
\text { a. being organized }\end{array}$ \\
\hline Future Goals & 9 & $\begin{array}{l}\text { How much do you think you will do these } \\
\text { things in the future (already has done, } \\
\text { definitely will, probably will, probably } \\
\text { won't, definitely won't, not sure)? } \\
\text { f. graduate from a 4-year college or } \\
\text { university }\end{array}$ \\
\hline Acceptability of & 1 & I would be interested in attending a program \\
\hline Educational Support & & like this (yes, definitely; maybe, it depends \\
\hline Program & & $\begin{array}{l}\text { on } \ldots \text {; not sure; no, I would not be } \\
\text { interested in attending this program) }\end{array}$ \\
\hline $\begin{array}{l}\text { Acceptability of } \\
\text { Educational Support }\end{array}$ & 14 & $\begin{array}{l}\text { What would encourage you to come to an } \\
\text { educational support program? }\end{array}$ \\
\hline Strategies & & e. getting help with financial aid for college \\
\hline
\end{tabular}

\section{School Performance}

School performance and special education services. Forty-percent of participants reported repeating a grade at some point in their school career. For participants in school $(n=28)$, the mean final grade in both English and math courses during the past school year was a $\mathrm{C}$.

Participants who had not been hospitalized during the current school year reported higher grades: 
$66.7 \%$ of those not hospitalized earned a grade of A or B in English and 50\% earned a grade of A or B in math versus $36.4 \%$ in math and 30\% in English for those who had been hospitalized. Regarding gender, more females reported earning an A in English than males $(33.3 \%$ of females versus $7.1 \%$ of males); more males reported earning an $\mathrm{A}$ in math than females $(21.4 \%$ of males versus $14.3 \%$ of females). Thirty-seven percent of participants reported receiving special education services (i.e., through an IEP or 504 Plan) during the past school year. Just over 75\% of participants diagnosed with the most severe SCD genotype (HbSS) reported that they received special education services.

Involvement in extracurricular activities. Almost half of participants (46.7\%) reported participation in a school-sponsored extracurricular activity (e.g., sports team, band) and $16.7 \%$ in a school-sponsored work activity (e.g., internship, work-study job). Outside of school, 43.3\% of participants were involved in a group activity (e.g., church youth group, sports team), 30\% participated in lessons (e.g., dance, music) and $23.3 \%$ had volunteered or participated in community service. In terms of gender, more females reported being involved in school or community extracurricular activities (range $=33.3 \%-53.3 \%$ ). Participants who were hospitalized at least one time in the previous year, as compared to those with no hospitalizations, reported more involvement in extracurricular activities. Specifically (1) $41.7 \%$ participated in lessons outside of school (versus $22.2 \%$ of those with no hospitalizations), (2) $58.3 \%$ participated in out-of-school groups (versus $33.3 \%$ of those with no hospitalizations), (3) $58.3 \%$ participated in school groups (versus $38.9 \%$ of participants with no hospitalizations), (4) $41.7 \%$ volunteered or participated in community service activities (versus $11.1 \%$ with no hospitalizations), and (5) $33.3 \%$ participated in school-sponsored work activities (versus only $5.6 \%$ of participants with no hospitalizations).

Educational goals. Many participants (63.3\%) reported planning to graduate from a 4-year college or university. Over a third $(43.3 \%)$ planned to complete technical or trade school or graduate from a 2-year or junior college (35.7\%; some participants chose more than one goal). With respect to gender, more females $(73.3 \%)$ reported that they "definitely" would graduate from a 4-year college or university (versus $46.7 \%$ of males); $20 \%$ of males endorsed that they "probably" or "definitely" would not graduate from a 4-year college or university. The majority of participants who had been hospitalized at least once (83.4\%) reported that they "definitely" or "probably" would graduate from a 2-year/junior college versus only $56.3 \%$ of those who had not been hospitalized.

\section{SCD Interference}

More than half of participants $(60.0 \%)$ reported that SCD interfered with their performance in school. More females reported SCD interference than males ( $80 \%$ versus $40 \%$ ). Seventy-five percent of those with at least one hospitalization reported that SCD interfered with school (versus only $25 \%$ in those without a hospitalization in the past year). With respect to work, $36.7 \%$ reported working at least part-time in the last 12 months with $23.3 \%$ of those endorsing that SCD interfered with their employment. 


\section{Demographics, School Performance and SCD Interference}

There were no significant relationships between age or number of hospitalizations ( 0 versus 1 or more), SCD interference and school performance (final grades in English [age $r=.257, p=.18$; hospitalizations $r=.261, p=.17$; SCD interference $r=-.030, p=.88$ ] or math [age $r=-.028, p$ $=.89$; hospitalizations $r=.210, p=.28$; SCD interference $r=-.030, p=.88$ ], repeating grades [age $r=.148, p=.43$; hospitalizations $r=.167, p=.38$; SCD interference $r=-.111, p=.56$ ], or receipt of special education services [age $r=-.121, p=.53$; hospitalizations $r=.226, p=.23$; SCD interference $r=-.056, p=.77]$ ). With respect to income, there was a medium effect size, $r$ $=-.494, p<.05$ according to Cohen (1988) in that lower income was negatively associated with grade retention.

\section{Acceptability and Need for Educational Support Strategies}

When asked whether they would be interested in attending an educational intervention program, over half of participants (56.7\%) responded "yes, definitely." Another third (33.3\%) responded, "maybe...it depends on..." Participants reported some possible barriers to participation including their school/work schedule, having their caregiver's consent, and other life circumstances such as where they would be living at the time. In terms of specific educational support strategies, at least half of participants indicated that they would be interested in job training, social activities, assistance with job applications, job interview practice, career decision guidance, college application assistance, and job shadowing. Less than half reported that they would be interested in the following strategies: discussion groups, homework assistance/tutoring, help with financial aid for college, and help with test taking (see Table 3 for complete results on potential educational strategies). In terms of gender, more females $(66.7 \%)$ reported being interested in participating in educational support strategies than males (46.7\%). Among participants who had been hospitalized at least once in the past year, $66.7 \%$ were interested in help with college applications, $66.7 \%$ in help with financial aid for college, and $66.7 \%$ in job shadowing.

Table 3

Acceptability of Educational Interventions

\begin{tabular}{lc}
\hline Specific intervention activities & \% interested $(n)$ \\
\hline Job training & $70.0(21)$ \\
Social activities & $63.3(19)$ \\
Help with job applications & $56.7(17)$ \\
Job interview practice & $53.3(16)$ \\
Career decision guidance & $50.0(15)$ \\
College application assistance & $53.3(16)$ \\
Job shadowing & $53.3(16)$ \\
Mentoring & $46.7(14)$ \\
Discussion groups & $43.3(13)$ \\
Homework assistance/tutoring & $36.7(11)$ \\
Help with financial aid & $40.0(12)$ \\
Help with test taking & $40.0(12)$ \\
Testing for school programs & $33.3(10)$ \\
\hline
\end{tabular}




\section{Discussion}

It is now widely recognized that adolescents with SCD are at increased risk for poor educational outcomes due to neurocognitive impairments and SCD-related school absences (Berkelhammer et al., 2007). Yet, there is limited research available about the school performance and educational needs of this population of students. This study is one of the first to describe adolescent perceptions of how SCD is impacting their school performance. It is also one of the first studies to include data about different types of educational support strategies these adolescents may perceive as beneficial. Study results indicated that adolescents with SCD were achieving average grades in core subjects (English and math), but $40 \%$ of participants reported that they had been retained at least one grade level during their school career. This retention rate is higher than national rates (24\%; Pharris-Ciurej, Hirschman, \& Willhoft, 2012). It is possible that the retention facilitated participants receiving average grades. Additional research is needed to understand factors that contribute to school performance in this population. In the interim, the study participant retention rate suggests that some adolescents with SCD may benefit from additional educational support to perform well in school.

More than a third $(36.7 \%)$ of participants in this sample reported receiving special education services. This is higher than the percent of children/adolescents $(13 \%)$ who are benefiting from special education in the general U.S. population (National Center for Education Statistics, 2014) and suggests that some adolescents with SCD may be receiving the educational accommodations they need. For example, only $11 \%$ of study participants receiving special education services reported failing math and no participants reported failing English. However, of the $60 \%$ of participants that reported that SCD interfered with their school performance, only $39 \%$ reported receiving special educational services in the past 12 months. This data suggests that more adolescents with SCD may need educational evaluations, accommodations and special education services.

Some participants were gainfully employed (36.7\%); yet, $23.3 \%$ of them noted that SCD interfered with their employment. These participants may be open to assistance with work accommodations that would serve to minimize the interference of SCD in the work environment, particularly given participant interest in support strategies such as job training, assistance with job applications, and job shadowing.

An examination of the relationship between demographic factors and school performance revealed that participants who resided in homes with lower incomes had higher rates of grade retention $(r=-.494, p<.05)$. This finding also supports the well-documented link between poverty and poor educational outcomes (Leventhal \& Brooks-Gunn, 2004) given that the mean family income for the sample was between $\$ 20,000$ and \$29,999. Future research with larger samples would allow for additional understanding of school performance, disease-related and socioeconomic variables.

Despite potential limitations due to their chronic illness, participants in this study reported developmentally appropriate educational goals such as pursuing post-secondary education. In fact, those with at least one hospitalization during the previous year tended to participate in educational and extracurricular activities, have post-secondary educational goals, and interest in 
receiving assistance with college applications, financial aid for college, and/or job shadowing experiences. This is an interesting finding and should be explored in future studies. It is unclear if this reflects the resiliency of these adolescents or if they attempt to compensate for missing school by participating in educational or extracurricular activities. It might also be that adolescents who are hospitalized more frequently receive more support services.

A little over half of participants in the sample expressed interest in educational support strategies. Their responses regarding the acceptability of specific strategies provided information about potential barriers and facilitators for participation. For example, educational programs that provide some flexibility may be best as participants expressed that participation would need to fit around their schedule. Participants were more interested in career-focused services (e.g., assistance with job applications and interviewing) than academic assistance (e.g., tutoring, testtaking). These participants may be most receptive to programs that offer a mix of career and academic strategies. It is unclear what is driving this interest in career-focused strategies. Adolescent preferences may have been influenced by academic history, age or socioeconomic status (e.g., job supports may be perceived as more tangible and applied) but this is difficult to determine given the small sample size.

\section{Limitations and Future Research}

The current study is not without limitations. Participants were approached at a SCD-related camp or community education event, which may have resulted in a biased sample as the patients enrolled were participating in support activities (e.g., camp, educational event). Despite this, the current sample was demographically similar (e.g., hemoglobin type, gender, income, health utilization) to the population of SCD patients served by our Comprehensive Sickle Cell Center (Hines et al., 2011; Mitchell, Carpenter, Crosby, Bishop, Hines, \& Noll, 2009).

Another limitation was the small sample size, which prohibited more sophisticated analyses and limited the generalizability of study findings. Though small, a sample size of 30 is consistent with sample sizes reported in other published pediatric SCD studies conducted at a single site that have guided the development of interventions (Patterson et al., 2014; Porter, Graff, Lopez, \& Hankins, 2014; Sobota et al., 2014). However, due to the small sample size, predictors, mediators or moderators of school performance that may be important in understanding the current or future educational/vocational outcomes in this population could not be examined. For example, research suggests that other factors such as parental level of education and neurocognitive functioning may play a role in academic achievement (Steen et al., 2005).

Future studies with more robust samples should seek to replicate and expand these findings by examining the relationship between school performance, socio-demographics (e.g., parental level of education, socioeconomic status), and disease factors (e.g., disease severity, treatment regimen). In addition, qualitative research studies (i.e., focus groups, in-depth interviews) may deepen the understanding of the educational needs of adolescents with SCD. Furthermore, the cross-sectional design of this study did not permit an examination of changes in SCD interference and school performance over time. Changes in educational needs are likely to occur because of changes in the treatment regimen, disease symptoms and complications, and individual and family factors (e.g., psychological functioning, family resources, social support). 
There were also limitations related to the measures. The Wave 2 Youth Survey adapted for this study was designed for 13 to 21 year olds; this measure was piloted with 12 year olds in the current study. Additional research is necessary to determine its validity and reliability with youth younger than age 13. Additionally, the current study did not include objective measures of school performance (e.g., report cards) or educational needs (e.g., academic or neuropsychological testing) nor did it include data from other informants (e.g., parents or teachers) who may provide a context for school performance.

\section{Conclusions}

Although SCD is the most common inherited blood disorder in the U.S., educators and schoolbased health personnel may not have previous exposure to the SCD population and the academic and health challenges they routinely encounter. Adolescents with SCD are a particularly understudied group; participant factors (racial/ethnic status, income level) and limited research funding have affected both study design and quantity. Consequently, there are few randomized control trials examining educational interventions (Koontz, Short, Kalinyak, \& Noll, 2004).

Study findings indicated that participants with SCD were achieving average grades but their retention rate appeared to be higher than the national average. Some participants who perceived that SCD interfered with school performance were not receiving educational support services. In general, participants were open to receiving educational support but strategies that include career-focused components may be more feasible and acceptable in this population. School health personnel have a unique opportunity to assist adolescents with SCD by assessing their educational needs, helping them obtain the support they need to achieve their academic goals, and counseling them to choose educational goals and careers consistent with their academic strengths and health limitations.

The value of the current study, similar to qualitative studies, is that it provides data that improves our understanding of the relationship between adolescent perception of school performance, educational needs and SCD interference and generates new research questions about risk factors. The study also provides data on the acceptability of educational strategies (e.g., tutoring, job shadowing) in this population and in doing so informs the development of academic and disease management interventions. More broadly, this study adds to the emerging literature on how to engage adolescents, including those with health needs, in designing developmentally appropriate educational support interventions (Galambos \& Leadbeater, 2000; Santelli et al., 2003).

\section{References}

Ashley-Koch, A., Yang, Q., \& Olney, R. S. (2000). Sickle hemoglobin (Hb S) allele and sickle cell disease: A HuGE review. American Journal of Epidemiology, 151(9), 839-845. http://dx.doi.org/10.1093/oxfordjournals.aje.a010288

Berkelhammer, L. D., Williamson, A. L., Sanford, S. D., Dirksen, C. L., Sharp, W. G., Margulies, A. S., \& Prengler, R. A. (2007). Neurocognitive sequelae of pediatric sickle cell disease: A review of the literature. Child Neuropsychology, 13(2), 120-131. http://dx.doi/org/10.1080/09297040600800956 
Brown, R. T., Buchanan, I., Doepke, K., Eckman, J. R., Baldwin, K., Goonan, B., \& Schoenherr, S. (1993). Cognitive and academic functioning in children with sickle cell disease. Journal of Clinical Child Psychology, 22, 207-218. http://dx.doi.org/10.1207/s15374424jecp2202_7

Brown, R. T., Doepke, K. J., \& Kaslow, N. J. (1993). Risk resistance adaptation model for pediatric chronic illness - sickle-cell syndrome as an example. Clinical Psychology Review, 13, 119-132. http://dx.doi.org/10.1016/0272-7358(93)90037-M

Cohen, J. (1988). Statistical power for the social sciences. Hillsdale, NJ: Laurence Erlbaum and Associates.

Day, S., \& Chismark, E. (2006). The cognitive and academic impact of sickle cell disease. The Journal of School Nursing, 22, 330-335. http://dx.doi.org/10.1177/10598405060220060401

DeBaun, M. R., Armstrong, F. D., McKinstry, R. C., Ware, R. E., Vichinsky, E., \& Kirkham, F. J. (2012). Silent cerebral infarcts: A review on a prevalent and progressive cause of neurologic injury in sickle cell anemia. Blood, 119(20), 4587-4596. http://dx.doi.org/10.1182/blood-2011-02-272682

Engelke, M. K., Guttu, M., Warren, M. B., \& Swanson, M. (2008). School nurse case management for children with chronic illness: Health, academic, and quality of life outcomes. The Journal of School Nursing, 24, 205-214. http://dx.doi.org/10.1177/1059840508319929

Galambos, N. L., \& Leadbeater, B. J. (2000). Trends in adolescent research for the new millennium. International Journal of Behavioral Development, 24(3), 289-294. http://dx.doi.org/10.1080/01650250050118268

Gil, K. M., Carson, J. W., Porter, L. S., Ready, J., Valrie, C., Redding-Lallinger, R., \& Daeschner, C. (2003). Daily stress and mood and their association with pain, health-care use, and school activity in adolescents with sickle cell disease. Journal of Pediatric Psychology, 28, 363-373. http://dx.doi.org/10.1093/jpepsy/jsg026

Herron, S., Bacak, S. J., King, A., \& DeBaun, M. R. (2003). Inadequate recognition of education resources required for high-risk students with sickle cell disease. Archives of Pediatrics and Adolescent Medicine, 157, 104. http://dx.doi.org/10.1001/archpedi.157.1.104

Hines, J., Mitchell, M. J., Crosby, L. E., Johnson, A., Valenzuela, J. M., Kalinyak, K., \& Joiner, C. (2011). Engaging patients with sickle cell disease and their families in disease education, research, and community awareness. Journal of Prevention \& Intervention in the Community, 39(3), 256-272. http://dx.doi.org/10.1080/10852352.2011.576976 
Human Genome Management Information System. (2013). Human genome project: Black bag. Retrieved from http://web.ornl.gov/sci/techresources/Human_Genome/publicat/jmmbbag.pdf

Kennedy, A., \& Sawyer, S. (2008). Transition from pediatric to adult services: Are we getting it right? Current Opinion in Pediatrics, 20, 403-409. http://dx.doi.org/ 10.1097/MOP.0b013e328305e128

King, A., Herron, S., McKinstry, R., Bacak, S., Armstrong, M., White, D., \& DeBaun, M. (2006). A multidisciplinary health care team's efforts to improve educational attainment in children with sickle-cell anemia and cerebral infarcts. Journal of School Health, 76, 33-37. http://dx.doi.org/10.1111/j.1746-1561.2006.00064.x

King, A. A., Tang, S. J., Ferguson, K. L., \& DeBaun, M. R. (2005). An education program to increase teacher knowledge about sickle cell disease. Journal of School Health, 75, 11-14. http://dx.doi.org/10.1111/j.1746-1561.2005.tb00003.x

Knight-Madden, J. M., Lewis, N., Tyson, E., Reid, M. E., \& MooSang, M. (2011). The possible impact of teachers and school nurses on the lives of children living with sickle cell disease. Journal of School Health, 81, 219-222. http://dx.doi.org/10.1111/j.17461561.2011.00582.x

Koontz, K., Short, A. D., Kalinyak, K., \& Noll, R. B. (2004). A randomized, controlled pilot trial of a school intervention for children with sickle cell anemia. Journal of Pediatric Psychology, 29, 7-17. http://dx.doi:10.1093/jpepsy/jsh002

Kral, M. C., Brown, R. T., Nietert, P. J., Abboud, M. R., Jackson, S. M., \& Hynd, G. W. (2003). Transcranial Doppler ultrasonography and neurocognitive functioning in children with sickle cell disease. Pediatrics, 112(2), 324-331. http://dx.doi.org/10.1542/peds.112.2.324

Leventhal, T., \& Brooks-Gunn, J. (2004). A randomized study of neighborhood effects on lowincome children's educational outcomes. Developmental Psychology, 40(4), 488. http://dx.doi.org/10.1037/0012-1649.40.4.488

Mitchell, M. J., Carpenter, G. J., Crosby, L. E., Bishop, C. T., Hines, J., \& Noll, J. (2009). Growth status in children and adolescents with sickle cell disease. Pediatric HematologyOncology, 26(4), 202-215. http://dx.doi.org/10.1080/08880010902896882

National Center for Education Statistics (2014, January). Children and youth with disabilities. Retrieved from https://nces.ed.gov/programs/coe/indicator_cgg.asp

National Dissemination Center for Children with Disabilities (2012). Other health impairment. Retrieved from http://nichcy.org/wp-content/uploads/docs/fs15.pdf

Newman, L., Wagner, M., Knokey, A. M., Marder, C., Nagle, K., Shaver, D., \& Wei, X. (2011). The post-high school outcomes of young adults with disabilities up to 8 years after high 
school: A report from the National Longitudinal Transition Study-2 (NLTS2). NCSER 2011-3005. National Center for Special Education Research.

Patterson, C. A., Chavez, V., Mondestin, V., Deatrick, J., Li, Y., \& Barakat, L. P. (2014). Clinical trial decision-making in pediatric sickle cell disease: A qualitative study of perceived benefits and barriers to participation. Journal of Pediatric Hematology/Oncology. http://dx.doi.org/10.1097/MPH.0000000000000216

Pharris-Ciurej, N., Hirschman, C., \& Willhoft, J. (2012). The 9th grade shock and the high school dropout crisis. Social Science Research, 41(3), 709-730. http://dx.doi.org/10.1016/j.ssresearch.2011.11.014

Porter, J. S., Graff, J. C., Lopez, A. D., \& Hankins, J. S. (2014). Transition from pediatric to adult care in sickle cell disease: Perspectives on the family role. Journal of Pediatric Nursing, 29(2), 158-167. http://dx.doi.org/10.1016/j.pedn.2013.10.002

Quinn, C. T., McKinstry, R. C., Dowling, M. M., Ball, W. S., Kraut, M. A., Casella, J. F., . . Kirkham, F. J. (2013). Acute silent cerebral ischemic events in children with sickle cell anemia. JAMA Neurology, 70(1), 58-65. http://dx.doi.org/10.1001/jamaneurol.2013.576

Quinn, C. T., Rogers, Z. R., McCavit, T. L., \& Buchanan, G. R. (2010). Improved survival of children and adolescents with sickle cell disease. Blood, 115(17), 3447-3452. http://dx.doi.org/10.1182/blood-2009-07-233700

Santelli, J. S., Rogers, A. S., Rosenfeld, W. D., DuRant, R. H., Dubler, N., Morreale, M., ... \& Schissel, A. (2003). Guidelines for adolescent health research: A position paper of the Society for Adolescent Medicine. Journal of Adolescent Health, 33(5), 396-409. http://dx.doi.org/10.1016/j.jadohealth.2003.06.009

Scantlebury, N., Mabbott, D., Janzen, L., Rockel, C., Widjaja, E., Jones, G., . . Odame, I. (2011). White matter integrity and core cognitive function in children diagnosed with sickle cell disease. Journal of Pediatric Hematology/Oncology, 33(3), 163-171. http://dx.doi.org/10.1097/MPH.0b013e3182036f33

Schwartz, L., Radcliffe, J., \& Barakat, L. P. (2006, September). Assessment of Health-Related Hindrance in Teens with Sickle Cell Disease. Poster session presented at the NIH Conference of National Centers of Sickle Cell Disease. Dallas, TX.

Schwartz, L. A., Radcliffe, J., \& Barakat, L. P. (2009). Associates of school absenteeism in adolescents with sickle cell disease. Pediatric Blood and Cancer, 52(1), 92-96. http://dx.doi.org/10.1002/pbc.21819

Sobota, A., Akinlonu, A., Champigny, M., Eldridge, M., McMahon, L., Telfair, J., \& Sprinz, P. (2014). Self-reported transition readiness among young adults with sickle cell disease. Journal of Pediatric Hematology/Oncology, 36(5), 389-394. http://dx.doi.org/10.1097/MPH.0000000000000110 
Steen, R. G., Fineberg-Buchner, C., Hankins, G., Weiss, L., Prifitera, A., \& Mulhern, R. K. (2005). Cognitive deficits in children with sickle cell disease. Journal of Child Neurology, 20(2), 102-107. http://dx.doi.org/10.1177/08830738050200020301

Taras, H., \& Potts-Datema, W. (2005). Chronic health conditions and student performance at school. Journal of School Health, 75(7), 255-266. http://dx.doi.org/10.1111/j.1746$\underline{1561.2005 .00034 . x}$

Telfair, J., Ehiri, J. E., Loosier, P. S., \& Baskin, M. L. (2004). Transition to adult care for adolescents with sickle cell disease: Results of a national survey. International Journal of Adolescent Medicine and Health, 16(1), 47-64. http://dx.doi.org/10.1515/IJAMH.2004.16.1.47

Thies, K. M. (1999). Identifying the educational implications of chronic illness in school children. Journal of School Health, 69(10), 392-397. http://dx.doi.org/10.1111/j.17461561.1999.tb06354.x

Thomas, P. W., Singhal, A., Hemmings-Kelly, M., \& Serjeant, G. R. (2000). Height and weight reference curves for homozygous sickle cell disease. Archives of Disease in Childhood, 82(3), 204-208. http://dx.doi.org/10.1136/adc.82.3.204

Varni, J. W., Seid, M., \& Kurtin, P. S. (2001). PedsQL ${ }^{\text {TM }}$ 4.0: Reliability and validity of the Pediatric Quality of Life Inventory ${ }^{\mathrm{TM}}$ Version 4.0 Generic Core Scales in healthy and patient populations. Medical Care, 39(8), 800-812. http://dx.doi.org/10.1097/00005650$\underline{200108000-00006}$

Wagner, M., Kutash, K., Duchnowski, A. J., \& Epstein, M. H. (2005). The special education elementary longitudinal study and the national longitudinal transition study: Study designs and implications for children and youth with emotional disturbance. Journal of Emotional and Behavioral Disorders, 13(1), 25-41. http://dx.doi.org/10.1177/10634266050130010301

Wagner, M., Newman, L., Cameto, R., Levine, P., \& Garza, N. (2006). An overview of findings from wave 2 of the National Longitudinal Transition Study-2 (NLTS2). NCSER 20063004. National Center for Special Education Research.

White, D. A., \& DeBaun, M. (1998). Cognitive and behavioral function in children with sickle cell disease: A review and discussion of methodological issues. Journal of Pediatric Hematology/Oncology, 20(5), 458-462. http://dx.doi.org/10.1097/00043426-199809000$\underline{00009}$ 